\title{
Serum GP73 predicts posthepatectomy outcomes in patients with hepatocellular carcinoma
}

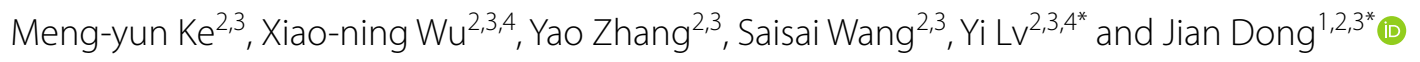

\begin{abstract}
Background and aims: Serum GP73 is a useful biomarker in assessing hepatic fibrosis degree. The aim of this study was to evaluate the predictive value of serum GP73 level for posthepatectomy short-term outcomes in hepatocellular carcinoma (HCC) patients.

Methods: A total of 280 patients undergoing liver resection for HCC between October 2015 and April 2018 were included in this study. Detailed preoperative clinicopathological data were collected and GP73 levels in serum obtained the day before hepatectomy were examined. Receiver operating characteristic (ROC) analysis was used to calculate the optimal cutoff of GP73, and independent risk factors for postoperative outcomes was assessed by logistic regression model.

Results: The mean GP73 level in patients was $111.8 \pm 153.3 \mathrm{ng} / \mathrm{mL}$. Serum GP73 levels were correlated with the METAVIR fibrosis score. Overall complications occurred in 145 patients and major complications developed in 29 patients. ROC analysis demonstrated that the predictive power of serum GP73 for postoperative outcomes was greater than the Child-Pugh score, ALBI score, FIB-4 index and APRI score. The optimal value of serum GP73 to predict overall complications and major complications was 80.9 and 79.2 respectively. Serum GP73 levels were independent factors affecting the incidence of overall complications (odds ratio [OR], 3.996; 95\% Cl 2.152-7.421; $\mathrm{P}<0.001$ ) and major complications (OR, 4.970; 95\% Cl 1.654-14.934; $\mathrm{P}=0.004)$ by multivariate analysis.
\end{abstract}

Conclusion: Serum GP73 is a useful tool to stratify HCC patients and to predict short-term outcomes after hepatectomy.

Keywords: GP73, Hepatocellular carcinoma, Liver fibrosis, Posthepatectomy outcomes

\section{Background}

Hepatocellular carcinoma (HCC) is one of the most common causes of death from cancer throughout the world [1]. Hepatectomy remains the most effective treatment aiming at cure. With improvements in perioperative patient care, resection technique, instrumentation, and

\footnotetext{
*Correspondence: luyi169@126.com; dong.jian@stu.xjtu.edu.cn

${ }^{3}$ National Local Joint Engineering Research Center for Precision Surgery

\& Regenerative Medicine, The First Affiliated Hospital of Xi'an Jiaotong

University, 277 West Yanta Road, Xi'an 710061, Shaanxi, China

${ }^{4}$ Department of Hepatobiliary Surgery, The First Affiliated Hospital of Xi'an Jiaotong University, 277 West Yanta Road, Xi'an 710061, Shaanxi,

China

Full list of author information is available at the end of the article
}

intensive care unit management, the postoperative morbidity and mortality have decreased significantly over the decades [2]. However, at the same time, the indication for liver resection has been gradually enlarged, and posthepatectomy morbidity remains a critical issue that needs to be cautious.

In recent decades, a number of markers, including liver function tests, and imaging modalities have been developed to evaluate the risk of adverse outcomes after hepatectomy [3, 4]. However, the predictive accuracy is moderate, and a more accurate biomarker is still in strong demand by clinicians.

Liver fibrosis and cirrhosis imply impaired liver function and coagulation function as well as performance

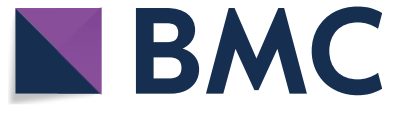

(c) The Author(s) 2019. This article is distributed under the terms of the Creative Commons Attribution 4.0 International License (http://creativecommons.org/licenses/by/4.0/), which permits unrestricted use, distribution, and reproduction in any medium, provided you give appropriate credit to the original author(s) and the source, provide a link to the Creative Commons license, and indicate if changes were made. The Creative Commons Public Domain Dedication waiver (http://creativecommons.org/ publicdomain/zero/1.0/) applies to the data made available in this article, unless otherwise stated. 
status. Prior studies have also demonstrated that liver cirrhosis affects liver regeneration after liver resection. Thus, liver cirrhosis is a noted adverse factor for morbidity and mortality after hepatectomy $[5,6]$. However, a long- standing problem with surgeons is that assessing the degree of liver fibrosis without liver biopsy is difficult before surgery. In most cases, the decision of hepatectomy could only be depended on the degree of liver cirrhosis assessed by the naked eye after laparotomy.

Golgi protein 73 (GP73) is a type II transmembrane glycoprotein that resides within the cis-Golgi complex normally [7]. GP73 contains a protease cleavage site, truncated GP73 cutted by protease can be secreted into the circulation $[8,9]$. The expression level of GP73 in liver tissue and serum is closely associated with liver disease, including acute hepatitis, liver cirrhosis and HCC. Recent studies have reported that GP73 is a powerful marker in predicting significant fibrosis in patients with chronic HBV infections [10, 11]. However, the function of GP73 for assessing the occurrence risk of postoperative adverse outcomes has not been elucidated. Thus, the aim of this study was to evaluate whether serum GP73 levels predict postoperative overall complications and major complications in HCC patients.

\section{Patients and methods}

The study was approved by the Clinical Research Ethics Committee of the First Affiliated Hospital of Xi'an Jiaotong University and was exempted from the requirement to obtain informed consent. The study protocol observed the ethical standards of the Helsinki Declaration.

Between October 2015 and April 2018, 280 HCC patients with Child-Pugh grade A or B, who underwent liver resection at the Department of Hepatobiliary Surgery, the First Affiliated Hospital of Xi'an Jiaotong University, were enrolled in this study.

The clinicopathological data analyzed in the present study included gender, age, diabetes, hypertension, ASA grading, total bilirubin, albumin, ALT, AST, size of tumor, number of tumors, operation time, blood loss, and transfusion of red blood cells. The values of ALBI score, APRI score and FIB-4 index were calculated according to the original formula reported previously [12-14]. Postoperative mortality was defined as death within 90 days after liver resection. The severity of postoperative complications was assessed according to the Dindo-Clavien classification. Major complications were defined as grade 3 or above [15]. The primary outcomes of this study was overall complication and major complication, the secondary outcomes included operative blood loss, blood transfusion and hospital stay.

\section{Measurement of serum levels of GP73}

For patients who underwent liver resection, a frozen serum sample was collected within 1 week before surgery and was stored at $-80^{\circ} \mathrm{C}$. The double-antibody sandwich enzyme-linked immunosorbent assay (ELISA) kit (Hotgen Biotech Inc., Beijing, China) was used to measure the serum GP73 values according to the manufacturer's protocol.

\section{Bioinformatics analysis of Oncomine cancer gene microarray database}

For analysis of GP73 mRNA expression in normal liver tissues, liver cirrhosis tissues and HCC tissues, we searched all the $8 \mathrm{HCC}$ datasets from the Oncomine database, only Mas datasets which included 19 normal liver tissues, 58 liver cirrhosis tissues and $38 \mathrm{HCC}$ tissues qualified for this study. This allowed us to compare GP73 transcript expression between different groups.

\section{Statistical analysis}

All statistical analyses were done using SPSS 24.0 software (SPSS, Chicago, IL). Continuous variables are described as the mean \pm standard deviation $(\mathrm{SD})$, and were compared by Student's t-test or Mann-Whitney $\mathrm{U}$ test, as appropriate. Categorical data are expressed as numbers and percentages, and compared with the $x^{2}$ test or Fisher's exact test. MedCalc software was used to develop the receiver operating curve (ROC) and the predictive accuracy of each index was compared using the method of DeLong. The optimal cutoff of serum GP73 value predicting postoperative outcomes was obtained by the receiver operating characteristic curves. Univariate and multivariate analyses were used to identify the independent risk factors for the development of postoperative primary outcomes. Only variables significantly associated with endpoints in the univariate analysis were subjected to the multivariate logistic regression analysis. All tests of significance were two-tailed, and $\mathrm{P}<0.05$ was considered statistically significant.

\section{Results \\ Patient characteristics}

The demographic and clinical characteristics of the enrolled patients are summarized in Table 1. The mean age of these patients (238 men and 42 women) was 50.9 years. One hundred and eighty-six patients had background viral hepatitis. Among these patients, 176 were positive for the HBV surface antigen, 8 were positive for the $\mathrm{HCV}$ antibody, and 2 patients were positive for both the HBV surface antigen and the HCV antibody. The majority of patients (93.6\%) belonged to 
Table 1 Subject characteristics

\begin{tabular}{|c|c|}
\hline Patient characteristics & n (\%) \\
\hline Age, mean $\pm S D$ (year) & $50.9 \pm 11.5$ \\
\hline Male, n (\%) & $238(85.0 \%)$ \\
\hline Diabetes, n (\%) & $22(7.9 \%)$ \\
\hline Hypertension, n (\%) & $53(18.9 \%)$ \\
\hline \multicolumn{2}{|l|}{ Background liver disease } \\
\hline $\mathrm{HB}$ & 176 \\
\hline $\mathrm{HC}$ & 8 \\
\hline $\mathrm{HB}$ and $\mathrm{HC}$ & 2 \\
\hline Non-B non-C & 94 \\
\hline ASA grading, mean + SD & $2.3 \pm 0.6$ \\
\hline Hemoglobin, mean \pm SD (g/dL) & $130.7 \pm 19.7$ \\
\hline White blood cell count, mean $\pm S D\left(10^{9} / L\right)$ & $5.5 \pm 2.5$ \\
\hline Platelet count, mean $\pm S D\left(10^{9} / L\right)$ & $135.8 \pm 71.0$ \\
\hline Total bilirubin, mean \pm SD $(\mu \mathrm{mol} / \mathrm{L})$ & $24.4 \pm 45.7$ \\
\hline $\mathrm{ALT}$, mean $\pm \mathrm{SD}(\mathrm{U} / \mathrm{L})$ & $54.2 \pm 57.1$ \\
\hline $\mathrm{AST}$, mean $\pm \mathrm{SD}(\mathrm{U} / \mathrm{L})$ & $56.8 \pm 63.2$ \\
\hline $\mathrm{INR}$, mean $\pm \mathrm{SD}$ & $1.08 \pm 0.1$ \\
\hline Albumin, mean $\pm S D(g / L)$ & $39.1 \pm 5.5$ \\
\hline GP73, mean \pm SD $(\mathrm{ng} / \mathrm{mL})$ & $111.8 \pm 153.3$ \\
\hline Child-Pugh score, mean \pm SD & $5.6 \pm 1.0$ \\
\hline Child-Pugh grade (A/B/C) & $262 / 18 / 0$ \\
\hline Size of largest tumor, mean \pm SD $(\mathrm{cm})$ & $6.2 \pm 3.6$ \\
\hline Solitary tumor, n (\%) & $246(87.9 \%)$ \\
\hline Blood loss, mean $\pm S D(\min )$ & $805.8 \pm 961.8$ \\
\hline Intermittent hilar clamping, mean \pm SD (min) & $14.3 \pm 15.2$ \\
\hline Operation time, mean \pm SD (min) & $233.5 \pm 200.2$ \\
\hline \multicolumn{2}{|l|}{ Intraoperative procedures } \\
\hline Minor hepatectomy & 199 \\
\hline Major hepatectomy & 81 \\
\hline \multicolumn{2}{|l|}{ Clavien-Dindo classification } \\
\hline Grade 1 & 35 \\
\hline Grade 2 & 81 \\
\hline Grade 3a/3b & $19 / 1$ \\
\hline Grade 4a/4b & $5 / 0$ \\
\hline Grade 5 & 4 \\
\hline
\end{tabular}

AST aspartate aminotransferase, ALT alanine aminotransferase, ASA American Society of Anesthesiology, $H B V$ hepatitis $B$ virus, $H C V$ hepatitis $C$ virus

Child-Pugh grade A and the remaining 18 had ChildPugh class B, there was no patient with Child-Pugh class C classification.

\section{Perioperative data}

The type of hepatectomy was anatomical liver resection, 199 patients underwent a minor hepatectomy and 81 patients underwent a major hepatectomy. The mean diameter of the largest tumors was $6.2 \pm 3.6 \mathrm{~cm}$, the mean operation time was $233.5 \pm 200.2 \mathrm{~min}$, and the mean operative blood loss was $805.8 \pm 961.8 \mathrm{~mL}$.
The overall complication rate was $58.0 \%$. Among these patients, 29 patients (10.4\%) had major complications, and only 4 patients (1.4\%) died within 3 months after surgery. Postoperative pathologic results showed that 33 patients had no fibrosis (F0), 55 patients had mild fibrosis (F1), 72 patients had severe fibrosis (F2), 62 patients had significant fibrosis (F3) and 58 patients had cirrhosis (F4).

\section{Correlation of GP73 to histological fibrosis staging}

A plot of serum GP73 in relation to the Metavir fibrosis stage is presented in Fig. 1a. The mean $( \pm S D)$ serum GP73 values in stage F0, F1, F2, F3, and F4 patients were $39.1 \pm 19.8,47.5 \pm 26.3,83.2 \pm 56.3,119.3 \pm 84.2$, and $241.2 \pm 278.2$, respectively. There were significant differences between stage F1 and stage F2, stage F2 and stage F3, and stage F3 and stage F4. The ROC curve for serum GP73 in relation to liver cirrhosis (F4) is shown in Fig. 1b. The AUROC of serum GP73 [0.792 (95\% confidence interval, $0.722-0.862 ; \mathrm{P}<0.001)$ ] was significantly higher than those for APRI and FIB-4 (Additional file 1: Table S1).

Next, we explored the expression levels of GP73 mRNA in human liver tissues from the Oncomine database. Only the Mas liver dataset had gene expression data for normal liver tissues, liver cirrhosis tissues and HCC tissues (Fig. 1c) [16]. The dataset revealed that the levels of GP73 mRNA in HCC tissues $(1.9 \pm 0.7)$ were higher than those in normal liver tissues $(1.0 \pm 0.8),(\mathrm{P}<0.001)$. Moreover, the expression levels of GP73 mRNA in liver cirrhosis tissues $(2.4 \pm 0.5)$ was even higher than that in HCC tissues $(\mathrm{P}<0.001)$. The ROC curve was used to assess the discriminatory power of GP73 mRNA for liver cirrhosis from normal liver. The AUROC value was 0.917 (95\% confidence interval, 0.820-1.000; $\mathrm{P}<0.001$ ) (Fig. 1d).

\section{Prediction of postoperative complications}

The ROC curves for serum GP73 and the other noninvasive markers in relation to postoperative overall complications are shown in Fig. 2a. The AUROC curve was 0.763 (95\% confidence interval, $0.708-0.818 ; \mathrm{P}<0.001$ ) for serum GP73, and the calculated cutoff value was $80.9 \mathrm{ng} / \mathrm{mL}$ with a sensitivity of $63.4 \%$, and a specificity of $80.0 \%$ in the prediction of overall complications (Table 2). The predictive accuracy of GP73 for postoperative overall complications is greater than other several markers. However, the superiority of serum GP73 over APRI and FIB-4 were not statistically significant.

The AUROC value for the serum GP73 (AUC 0.756, 95\% CI, $0.668-0.845 ; \mathrm{P}<0.001)$ in predicting postoperative severe complications was greater than that for the other markers, but the statistically significance between GP73 and ALBI and APRI was not observed (Fig. 2b). The optimal cut-off value of serum GP73 was 

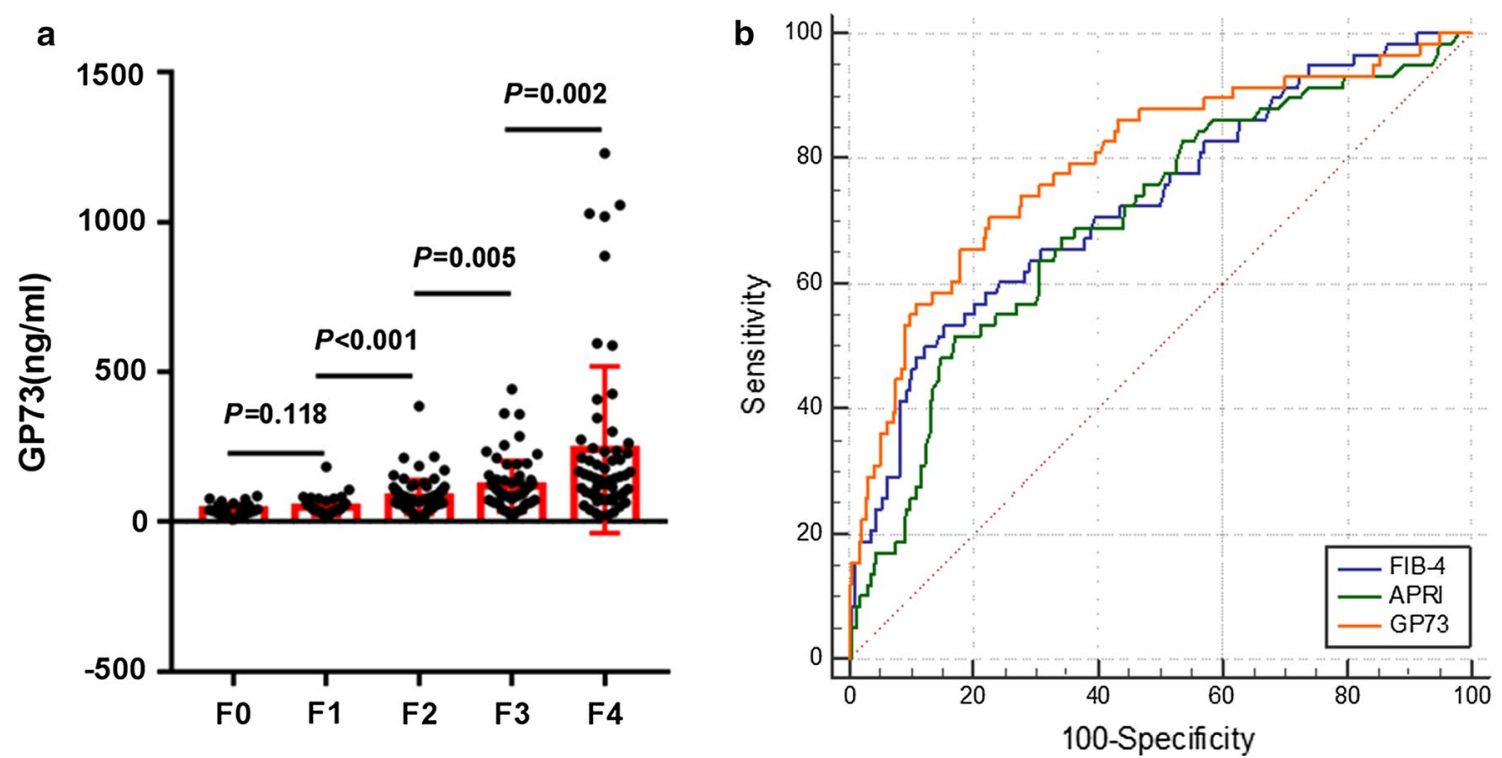

C

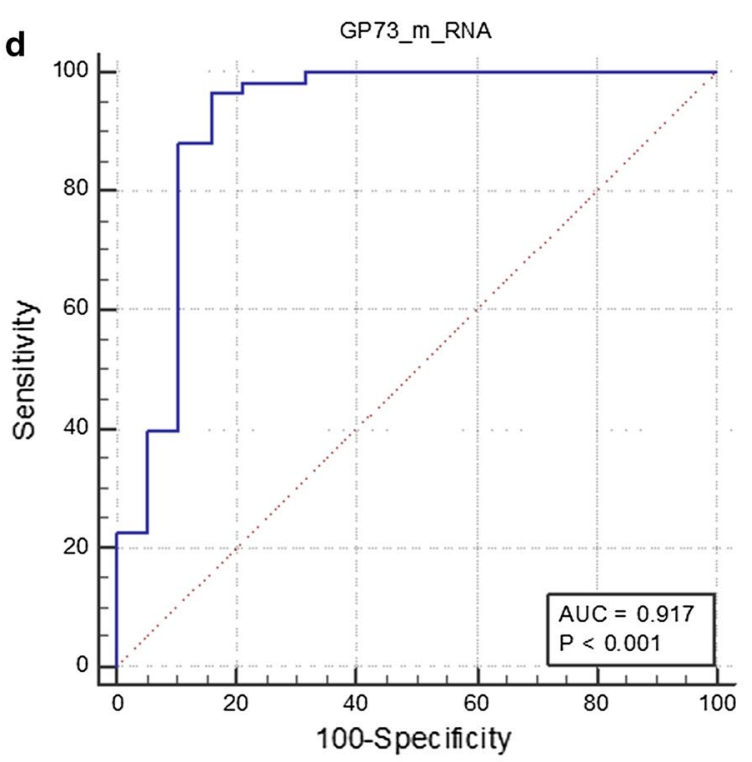

Fig. 1 Serum GP73 values for each Metavir fibrosis stage (a); ROC curve for serum GP73 in relation to liver cirrhosis (b); GP73 mRNA levels for normal liver tissues, liver cirrhosis tissues and HCC tissues in the Mas liver dataset (c); ROC curve for GP73 mRNA levels in relation to liver cirrhosis in the Mas liver dataset $(\mathbf{d})$

$79.2 \mathrm{ng} / \mathrm{mL}$ with a sensitivity of $82.8 \%$ and a specificity of $60.2 \%$ for postoperative severe complications.

The distributions of serum GP73 values according to the occurrence of postoperative overall complication and major complication were shown in Fig. 3. The serum GP73 value of the complication-positive group was significantly higher than that of the complicationnegative group.

\section{Risks factors of posthepatectomy outcomes}

First, serum GP73 values were transformed into categorical data on the basis of the cutoff value in the logistic regression model. Univariate analysis showed that age, total bilirubin, albumin, ALT, AST, GP73, operation time, blood loss, and intraoperative red blood cell transfusion were significant predictors of overall complications after hepatectomy. In the multivariate analysis, albumin (odds 

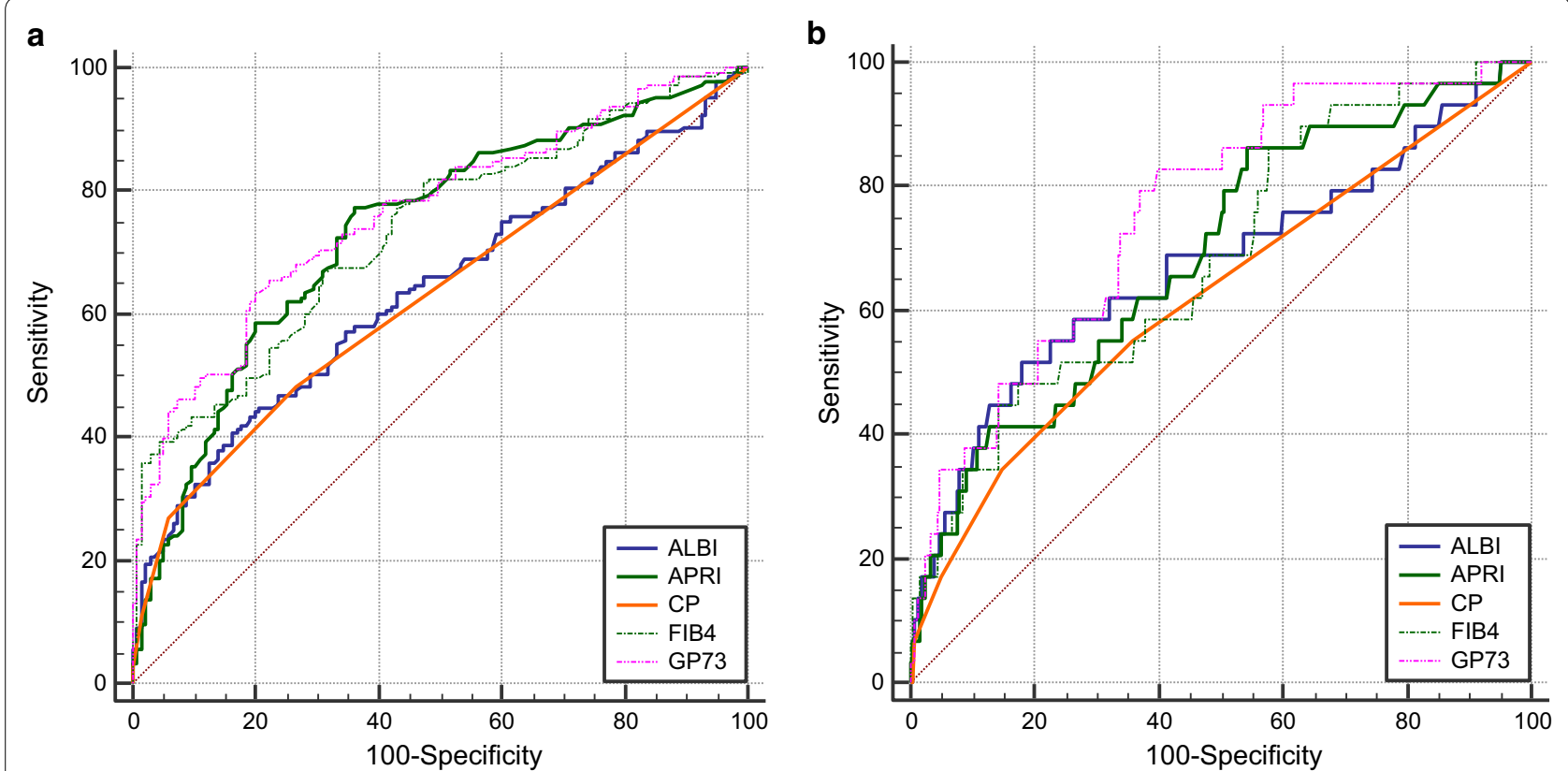

Fig. 2 Receiver operating characteristic (ROC) curves for noninvasive markers in prediction of postoperative overall complications (a) and major complications (b)

Table 2 Receiver operating characteristic analysis of noninvasive markers in predicting postoperative outcomes

\begin{tabular}{lcccc}
\hline Variable(s) & Area & $\boldsymbol{P}$ value & $\begin{array}{l}\boldsymbol{P} \text { value* } \\
\text { GP73) }\end{array}$ & $\mathbf{9 5 \%} \mathrm{Cl}$ \\
\hline Overall morbidity & & & & \\
GP73 & 0.763 & $<0.001$ & & $0.708-0.818$ \\
ALBI & 0.637 & $<0.001$ & 0.001 & $0.573-0.702$ \\
FIB-4 & 0.734 & $<0.001$ & 0.159 & $0.676-0.792$ \\
APRI & 0.733 & $<0.001$ & 0.271 & $0.674-0.792$ \\
Child-Pugh score & 0.631 & $<0.001$ & $<0.001$ & $0.566-0.696$ \\
Severe morbidity & & & & \\
GP73 & 0.756 & $<0.001$ & & $0.668-0.845$ \\
ALBI & 0.671 & 0.003 & 0.102 & $0.551-0.790$ \\
FIB-4 & 0.684 & 0.001 & 0.037 & $0.580-0.787$ \\
APRI & 0.687 & 0.001 & 0.155 & $0.584-0.790$ \\
Child-Pugh score & 0.622 & 0.031 & 0.027 & $0.506-0.739$ \\
\hline
\end{tabular}

*P value, comparisons of respective AUROC of other method with that of GP73

ratio $[\mathrm{OR}]=0.922 ; 95 \%$ confidence interval $[\mathrm{CI}] 0.871-$ $0.975 ; \mathrm{P}=0.004)$, ALT $(\mathrm{OR}=1.012 ; 95 \%$ CI 1.001-1.022; $\mathrm{P}=0.026)$, GP73 of $80.9 \mathrm{ng} / \mathrm{mL}$ or greater $(\mathrm{OR}=3.996$; 95\% CI 2.152-7.421; $\mathrm{P}<0.001)$, and intraoperative red blood cell transfusion $(\mathrm{OR}=1.206$; $95 \%$ CI 1.069-1.359; $\mathrm{P}=0.002)$, were independently associated with overall complications (Table 3).

Albumin, ALT, AST, GP73, blood loss, and intraoperative red blood cell transfusion were significantly related to postoperative major complications at univariate analysis. Three independent predictors of major complications were identified at multivariate analysis: ALT $(\mathrm{OR}=1.006$; 95\% CI 1.001-1.011; $\mathrm{P}=0.019)$, GP73 of $79.2 \mathrm{ng} / \mathrm{mL}$ or greater $(\mathrm{OR}=4.970 ; 95 \%$ CI $1.654-14.934 ; \mathrm{P}=0.004)$, and blood loss $(\mathrm{OR}=1.001 ; 95 \%$ CI 1.000-1.001; $\mathrm{P}<0.001$; Table 4).

\section{Patients characteristics according to serum GP73 levels}

Table 5 reports the characteristics of patients according to serum GP73 levels. Patients with elevated GP73 levels had a higher ASA grading, higher Child-Pugh score, and higher preoperative levels of total bilirubin, ALT, AST, albumin, white blood cell, platelet count, and INR. Besides, the intraoperative transfusion of red blood cells and fresh frozen plasma was also significantly higher in patients with GP73 $>80.9 \mathrm{ng} / \mathrm{mL}$. After surgery, there were significant differences in complication rates, and hospital stays between patients with GP73 $\leq 80.9$ and $>80.9 \mathrm{ng} / \mathrm{mL}$. In addition, no significant differences in the tumor characteristics were observed between the two groups. Serum total bilirubin was significantly higher in patients with GP73 $>80.9 \mathrm{ng} / \mathrm{mL}$ than in patients with GP73 $\leq 80.9$ on PODs (postoperative days) 1,3 , and $7(44.4 \pm 63.6$ vs $25.5 \pm 15.2, P=0.002 ; 51.0 \pm 67.0$ vs $31.6 \pm 30.1 \mathrm{pg} / \mathrm{mL}, P=0.008$; and $53.0 \pm 101.6$ vs $25.1 \pm 19.6, P=0.006$; respectively). The peak of the serum total bilirubin occurred on the third postoperative day in patients with GP73 $\leq 80.9$, whereas, the level 

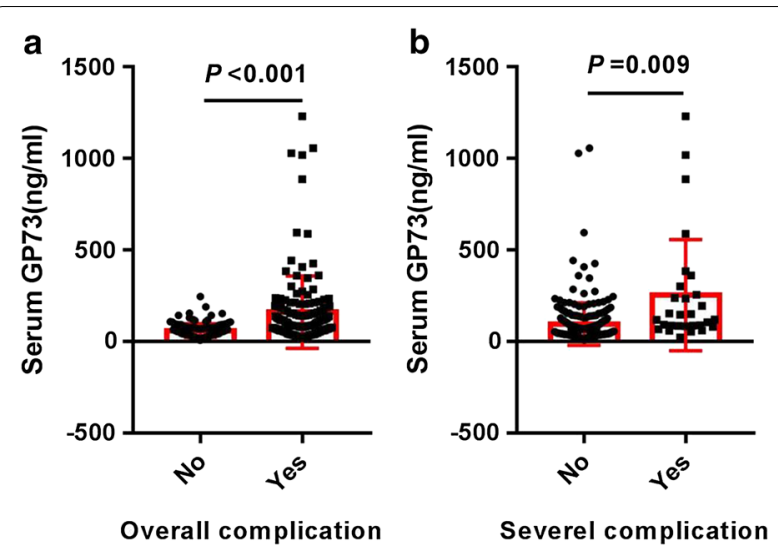

Fig. 3 Distribution of serum GP73 values according to the occurrence of overall complications (a) and severe complications (b)

of serum total bilirubin has generally increased over 7 days after the operation. The albumin level was lower in patients with GP73 $>80.9 \mathrm{ng} / \mathrm{mL}$ than in patients with GP73 $\leq 80.9 \mathrm{ng} / \mathrm{mL}$ on PODs 1 and $3(33.3 \pm 4.9$ vs $31.9 \pm 5.7, P=0.049$; and $34.6 \pm 4.8$ vs $33.0 \pm 5.2 \mathrm{pg} / \mathrm{mL}$, $P=0.015$; respectively; Fig. 4).

\section{Discussion}

Posthepatectomy complications remains an issue that deserves concern for surgeons in clinic, and accurate evaluation of preoperative risk factors is essential to prevent postoperative morbidity and mortality.
Liver fibrosis and cirrhosis, which often accompany HCC are well-known risk factors for liver resection [17]. From the perspective of molecular biology, expression levels of many damage-associated molecular patterns are up-regulated in the progression of liver fibrosis, and these damage-associated molecular patterns make liver more sensitive to ischemia/reperfusion injury [18]. On the other hand, lower levels of hepatocyte growth factor and other transcription factors in cirrhotic livers weaken liver regeneration after liver resection [19, 20]. Hence, precise assessment of the degree of liver fibrosis is an important method to predict the operative risk.

Several non-invasive tools have been developed in the assessment of liver fibrosis [21, 22]. Among them, liver stiffness has the most efficacy. A previous study reported that the corresponding AUROC of liver stiffness for the diagnosis of cirrhosis was 0.96 in patients with HCV, 0.90 in patients with HBV, and 0.96 in patients with either alcoholic or nonalcoholic steatohepatitis [23]. The only fly in the ointment is that liver stiffness is costly and requires technical or expert knowledge. Recently, several studies have confirmed the efficacy of GP73 in assessing liver fibrosis. Cao et al. [24] demonstrated that serum GP73 is a powerful serum marker, and its diagnostic accuracy was comparable to liver stiffness and significantly higher than APRI score and FIB-4 index in antiviral-naïve chronic HBV infection. Similar to previous results, the serum GP73 level in the current study demonstrated a significant correlation with liver fibrosis. GP73 showed a high accuracy in predicting liver cirrhosis.

Table 3 Univariate and multivariate analysis of postoperative overall complications

\begin{tabular}{|c|c|c|c|c|c|}
\hline \multirow[t]{2}{*}{ Variables } & \multirow{2}{*}{$\begin{array}{l}\text { No complications } \\
135\end{array}$} & \multirow{2}{*}{$\begin{array}{l}\text { Complications } \\
145\end{array}$} & \multirow{2}{*}{$\begin{array}{l}\text { Univariate } \\
\text { analysis } \\
P\end{array}$} & \multicolumn{2}{|c|}{ Multivariate analysis } \\
\hline & & & & OR $(95 \% \mathrm{Cl})$ & $P$ \\
\hline Gender (male/female) & $116 / 19$ & $122 / 23$ & 0.675 & & \\
\hline Age (year) $(\leq 50$ vs $>50)$ & $69 / 66$ & $62 / 83$ & 0.027 & & \\
\hline Diabetes (yes vs no) & $9 / 126$ & $13 / 132$ & 0.475 & & \\
\hline Hypertension (yes vs no) & $24 / 111$ & 29/116 & 0.635 & & \\
\hline ASA grading $(\leq 2$ vs $>2)$ & $101 / 34$ & $94 / 51$ & 0.069 & & \\
\hline Total bilirubin ( $\mu \mathrm{mol} / \mathrm{L})$ & $15.2 \pm 8.0$ & $33.0 \pm 61.9$ & 0.001 & & \\
\hline Albumin (g/L) & $40.7 \pm 5.1$ & $37.7 \pm 5.5$ & $<0.001$ & $0.922(0.871-0.975)$ & 0.004 \\
\hline $\operatorname{ALT}(\mathrm{U} / \mathrm{L})$ & $38.0 \pm 23.0$ & $69.4 \pm 73.3$ & $<0.001$ & $1.012(1.001-1.022)$ & 0.026 \\
\hline AST (U/L) & $37.7 \pm 19.7$ & $74.4 \pm 81.9$ & $<0.001$ & & \\
\hline GP73 ( $\leq 80.9$ vs $>80.9 \mathrm{ng} / \mathrm{mL})$ & $108 / 27$ & $53 / 92$ & $<0.001$ & $3.996(2.152-7.421)$ & $<0.001$ \\
\hline Size of tumor $(\mathrm{cm})$ & $6.1 \pm 3.4$ & $6.3 \pm 3.8$ & 0.749 & & \\
\hline Number of tumors & $1.1 \pm 0.4$ & $1.2 \pm 0.5$ & 0.521 & & \\
\hline Operation time (min) & $200.9 \pm 65.4$ & $263.9 \pm 267.9$ & 0.008 & & \\
\hline Blood loss (mL) & $546.1 \pm 510.5$ & $1051.0 \pm 1197.5$ & $<0.001$ & & \\
\hline Intraoperative RBC transfusion & $1.9 \pm 2.0$ & $3.8 \pm 4.3$ & $<0.001$ & $1.206(1.069-1.359)$ & 0.002 \\
\hline
\end{tabular}

AST aspartate aminotransferase, $A L T$ alanine aminotransferase, $A S A$ American Society of Anesthesiology, $R B C$ red blood cell 
Table 4 Univariate and multivariate analysis of postoperative severe complications

\begin{tabular}{|c|c|c|c|c|c|}
\hline \multirow[t]{2}{*}{ Variables } & \multirow{2}{*}{$\begin{array}{l}\text { No complications } \\
251\end{array}$} & \multirow{2}{*}{$\begin{array}{l}\text { Complications } \\
29\end{array}$} & \multirow{2}{*}{$\begin{array}{l}\text { Univariate } \\
\text { analysis } \\
P\end{array}$} & \multicolumn{2}{|l|}{ Multivariate analysis } \\
\hline & & & & OR $(95 \% \mathrm{Cl})$ & $P$ \\
\hline Gender & $217 / 34$ & $21 / 8$ & 0.045 & & \\
\hline Age (year) $(\leq 50$ vs $>50)$ & $117 / 134$ & $14 / 15$ & 0.865 & & \\
\hline Diabetes (yes vs no) & $19 / 232$ & $3 / 26$ & 0.486 & & \\
\hline Hypertension (yes vs no) & $46 / 205$ & $7 / 22$ & 0.449 & & \\
\hline ASA grading ( $\leq 2$ vs $>2$ ) & $178 / 73$ & $17 / 12$ & 0.173 & & \\
\hline Total bilirubin ( $\mu \mathrm{mol} / \mathrm{L})$ & $20.6 \pm 33.5$ & $57.6 \pm 97.3$ & 0.052 & & \\
\hline Albumin (g/L) & $39.4 \pm 5.6$ & $36.9 \pm 4.1$ & 0.021 & & \\
\hline $\mathrm{ALT}(\mathrm{U} / \mathrm{L})$ & $48.8 \pm 42.8$ & $100.6 \pm 116.6$ & 0.024 & $1.006(1.001-1.011)$ & 0.019 \\
\hline AST (U/L) & $51.1 \pm 52.7$ & $106.2 \pm 110.6$ & 0.013 & & \\
\hline GP73 ( $\leq 79.2$ vs > $79.2 \mathrm{ng} / \mathrm{mL}$ ) & $151 / 100$ & $5 / 24$ & $<0.001$ & $4.970(1.654-14.934)$ & 0.004 \\
\hline Size of tumor $(\mathrm{cm})$ & $6.1 \pm 3.5$ & $7.3 \pm 4.5$ & 0.065 & & \\
\hline Number of tumors & $1.2 \pm 0.5$ & $1.1 \pm 0.4$ & 0.785 & & \\
\hline Operation time (min) & $230.0 \pm 208.7$ & $263.8 \pm 98.6$ & 0.390 & & \\
\hline Blood loss (mL) & $705.3 \pm 789.9$ & $1669.0 \pm 1662.6$ & 0.004 & $1.001(1.000-1.001)$ & $<0.001$ \\
\hline Intraoperative RBC transfusion & $2.5 \pm 2.9$ & $6.0 \pm 6.5$ & $<0.001$ & & \\
\hline
\end{tabular}

AST aspartate aminotransferase, ALT alanine aminotransferase, ASA American Society of Anesthesiology, RBC red blood cell

Based on this result, we evaluated the usefulness of serum GP73 in predicting postoperative outcomes. In the present study, multivariable analysis revealed that the serum GP73 level was an independent predictor of postoperative overall complications and major complications. Furthermore, we found that $80.9 \mathrm{ng} / \mathrm{mL}$ should be the critical value of the serum GP73 for postoperative riskstratification. On the basis of this critical value, patients with elevated GP73 levels displayed worse liver function, coagulation function and basic status, and consequent higher blood loss, increased blood transfusion and longer hospital stays come with these patients. Furthermore, patients with elevated GP73 levels showed a slower recovery of liver function after surgery. In the end, the overall and major complication rates were significantly higher in patients with GP73 $>80.9 \mathrm{ng} / \mathrm{mL}$. The cutoff value at $80.9 \mathrm{ng} / \mathrm{mL}$ was helpful in risk stratification for patients with hepatocellular carcinoma.

The Child-Pugh score is a traditional liver function index which has been widely used in clinic. The albumin-bilirubin (ALBI) score which is another new liver serve maker reported by Johnson and colleagues, it has been validated to be a useful tool to assess the posthepatectomy short-term and long-term prognosis for HCC patients [25-27]. In addition, other noninvasive liver fibrosis tools including FIB-4 index and APRI score also have the power to evaluate liver function reserve. Assessment of liver function is particularly important for HCC patients who are prepared for surgery, because it is perceived that liver cirrhosis is a major cause of death. Our results demonstrated that the serum GP73 level had a greater discriminatory power than the other noninvasive models in predicting postoperative overall complications and major complications. Thus, serum GP73 is a excellent tool that can reflect the liver function of HCC patients very well.

Recently, researches reported that serum GP73 is a potential diagnostic marker for HCC $[28,29]$. However, some other studies showed that the elevated levels of serum GP73 in HCC patients were mainly due to the background of liver cirrhosis [30]. In the present study, the Oncomine dataset showed that the GP73 expression levels in the liver cirrhosis tissues were the highest among the normal liver tissues, liver cirrhosis tissues and HCC tissues. In addition, the tumor characters including tumor size and tumor number showed no significant differences between patients with GP73 $\leq 80.9$ and $>80.9 \mathrm{ng} / \mathrm{mL}$. A study by Liu et al. [31] also demonstrated that serum GP73 increased in HCC patients with cirrhosis but not in those without cirrhosis, and all these results suggested that the background of cirrhosis but not HCC was related to the upregulation of serum GP73.

In the current study, GP73 did not improve prediction of postoperative outcomes significantly compared with traditional markers. However, as we often encounter a difficult situation that various traditional liver function tests show inconsistent results in judging actual liver function and we suppose that measuring GP73 in addition to conventional liver function markers is helpful for our judgment especially in such situations. 
Table 5 Baseline comparison between patients with GP73 $>80.9$ and $\leq 80.9$

\begin{tabular}{|c|c|c|c|}
\hline Variable & $\begin{array}{l}\text { GP73 } \leq 80.9 \mathrm{ng} / \mathrm{mL} \\
(\mathrm{n}=161)\end{array}$ & $\begin{array}{l}\text { GP73 }>80.9 \mathrm{ng} / \mathrm{mL} \\
(\mathrm{n}=119)\end{array}$ & $P$ \\
\hline Age, mean \pm SD (year) & $51.3 \pm 11.9$ & $50.3 \pm 11.0$ & 0.972 \\
\hline Gender (male/female) & $135 / 26$ & $103 / 16$ & 0.531 \\
\hline Diabetes (yes vs no) & $13 / 148$ & $9 / 110$ & 0.875 \\
\hline Hypertension (yes vs no) & $31 / 130$ & 22/97 & 0.871 \\
\hline $\mathrm{ASA}$ grading, mean $\pm S D$ & $2.2 \pm 0.6$ & $2.3 \pm 0.6$ & 0.046 \\
\hline Total bilirubin, mean $\pm S D(\mu \mathrm{mol} / \mathrm{L})$ & $16.3 \pm 11.6$ & $35.5 \pm 67.3$ & $<0.001$ \\
\hline $\mathrm{ALT}$, mean $\pm \mathrm{SD}(\mathrm{U} / \mathrm{L})$ & $34.8 \pm 18.9$ & $80.3 \pm 77.5$ & $<0.001$ \\
\hline $\mathrm{AST}$, mean $\pm \mathrm{SD}(\mathrm{U} / \mathrm{L})$ & $34.7 \pm 14.8$ & $86.8 \pm 87.0$ & $<0.001$ \\
\hline Albumin, mean \pm SD (g/L) & $40.1 \pm 5.2$ & $37.8 \pm 5.5$ & $<0.001$ \\
\hline Child-Pugh score, mean \pm SD & $5.4 \pm 0.8$ & $5.9 \pm 1.1$ & $<0.001$ \\
\hline $\mathrm{WBC}$, mean $\pm \mathrm{SD}\left(10^{9} / \mathrm{L}\right)$ & $5.9 \pm 2.4$ & $4.9 \pm 2.4$ & 0.001 \\
\hline Hemoglobin, mean $\pm S D$ (g/dL) & $132.3 \pm 21.0$ & $128.5 \pm 17.6$ & 0.104 \\
\hline Platelet count, mean $\pm \mathrm{SD}\left(10^{9} / \mathrm{L}\right)$ & $165.6 \pm 73.6$ & $95.5 \pm 41.5$ & $<0.001$ \\
\hline $\mathrm{PT}$, mean $\pm \mathrm{SD}$ & $13.2 \pm 1.2$ & $13.5 \pm 1.4$ & 0.022 \\
\hline APTT, mean \pm SD & $37.7 \pm 7.4$ & $38.0 \pm 8.2$ & 0.758 \\
\hline $\mathrm{INR}$, mean $\pm \mathrm{SD}$ & $1.06 \pm 0.10$ & $1.10 \pm 0.11$ & 0.001 \\
\hline Size of tumor, mean $\pm S D(\mathrm{~cm})$ & $5.9 \pm 3.5$ & $6.5 \pm 3.7$ & 0.183 \\
\hline Number of tumors & $1.2 \pm 0.5$ & $1.2 \pm 0.4$ & 0.798 \\
\hline Operation time, mean $\pm S D$ (min) & $217.0 \pm 80.9$ & $255.8 \pm 291.6$ & 0.109 \\
\hline Blood loss, mean $\pm S D(m L)$ & $677.3 \pm 856.3$ & $980.1 \pm 1067.9$ & 0.012 \\
\hline \multicolumn{4}{|l|}{ Blood transfusion } \\
\hline Red blood cells, mean $\pm S D(u)$ & $2.3 \pm 3.2$ & $3.6 \pm 3.9$ & 0.003 \\
\hline Fresh frozen plasma, mean $\pm \mathrm{SD}(\mathrm{mL})$ & $224.8 \pm 350.5$ & $317.7 \pm 330.3$ & 0.026 \\
\hline Cryoprecipitation, mean \pm SD (u) & $0.6 \pm 1.8$ & $8.5 \pm 73.6$ & 0.245 \\
\hline \multicolumn{4}{|l|}{ Complication } \\
\hline Overall & $53 / 108$ & $92 / 27$ & $<0.001$ \\
\hline Severe & $6 / 155$ & $23 / 96$ & $<0.001$ \\
\hline Total hospital stay, mean \pm SD (day) & $20.6 \pm 6.9$ & $24.1 \pm 8.3$ & $<0.001$ \\
\hline Postoperative hospital stay, mean $\pm \mathrm{SD}$ (day) & $13.5 \pm 5.7$ & $15.7 \pm 6.1$ & 0.002 \\
\hline Length of ICU stay, mean \pm SD (day) & $2.6 \pm 1.5$ & $2.8 \pm 1.3$ & 0.233 \\
\hline
\end{tabular}

AST aspartate aminotransferase, ALT alanine aminotransferase, ASA American Society of Anesthesiology, FIB-4 fibrosis score 4, WBC white blood cell
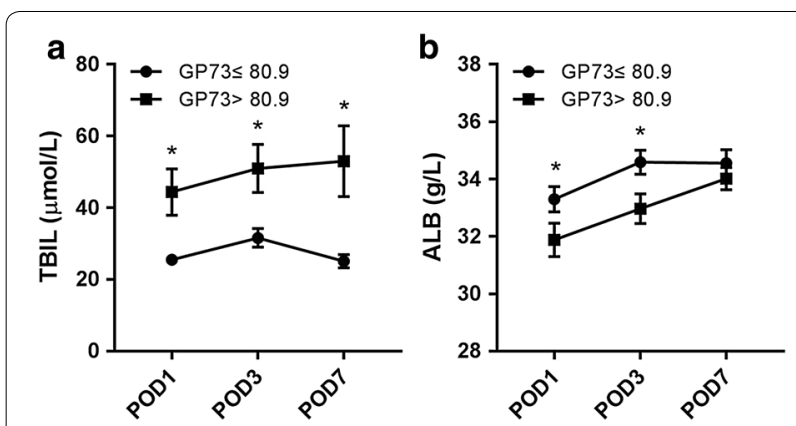

Fig. 4 Postoperative liver injury assessed by measurements of serum total bilirubin (a) and albumin (b) for patients with GP73 > 80.9 and $\leq 80.9 \mathrm{ng} / \mathrm{mL}$. POD postoperative day; ${ }^{*}$ significant
The present study has several limitations. First, the absence of liver stiffness measurements makes it impossible to compare the diagnostic accuracy in predicting postoperative outcomes between serum GP73 and liver stiffness. Second, the majority of patients had a background of hepatitis B virus, which is different from Western countries where the etiology is predominantly hepatitis $C$ virus, other etiological cases are required to validate the application ability of GP73. Third, HCC patients with Child-Pugh grade $\mathrm{C}$ were excluded for liver resection at the local centre, only 4 (1.42\%) patients died within 3 months after surgery, and the sample size and the number of events were relatively small. Futhermore, there was a lack of validation of the 
results with an independent population. Thus, a multicenter prospective study is needed to assess the efficacy of GP73 in predicting postoperative outcomes. However, even with these limitations, to our knowledge, the role of preoperative serum GP73 to predict the shortterm outcomes after hepatectomy in HCC patients has never been previously explored, and to date, it is the first time for this study to report a clear correlation between preoperative serum GP73 and postoperative complication.

\section{Conclusion}

In conclusion, our study demonstrated that GP73 is a valuable serum marker that can be used clinically to stratify patients with a high risk of postoperative complications by reflecting the status of liver fibrosis. Measurements of GP73 will also help to select the right HCC patients to undergo surgical treatment. Therefore, we recommend measuring serum GP73 levels as a routine examination for HCC patients undergoing hepatectomy. It will be interesting to combine GP73 with other markerss to seek further improvement of accuracy in future investigations.

\section{Additional file}

Additional file 1: Table S1. Receiver Operating Characteristic Analysis of Noninvasive Markers in Diagnosing Liver Cirrhosis.

\section{Authors' contributions}

Study conception and design: YL, JD; acquisition of data: XW, YZ, SW; analysis and interpretation of data: JD; drafting of manuscript: MK, JD. All authors read and approved the final manuscript.

\section{Author details \\ ${ }^{1}$ Department of Vascular Surgery, First Affiliated Hospital of Xi'an Jiaotong University, Xi'an, Shaanxi, China. ${ }^{2}$ Institute of Advanced Surgical Technology and Engineering, The First Affiliated Hospital of Xi'an Jiaotong University, 277 West Yanta Road, Xi'an 710061, Shaanxi, China. ${ }^{3}$ National Local Joint Engineering Research Center for Precision Surgery \& Regenerative Medicine, The First Affiliated Hospital of Xi'an Jiaotong University, 277 West Yanta Road, Xi'an 710061, Shaanxi, China. ${ }^{4}$ Department of Hepatobiliary Surgery, The First Affiliated Hospital of Xi'an Jiaotong University, 277 West Yanta Road, Xi'an 710061, Shaanxi, China.}

\section{Acknowledgements}

Not applicable.

\section{Competing interests}

The authors declare that they have no competing interests.

\section{Availability of data and materials}

Not applicable.

\section{Consent for publication}

Informed consent was obtained from each patient prior to study onset.
Ethics approval and consent to participate

The study was approved by the Ethics Committee at the The First Affiliated Hospital of Xi'an Jiaotong University.

\section{Funding}

This study was supported in part by National Natural Science Foundation (Nos. 81700560 and 81702434).

\section{Publisher's Note}

Springer Nature remains neutral with regard to jurisdictional claims in published maps and institutional affiliations.

Received: 15 February 2019 Accepted: 19 April 2019

Published online: 02 May 2019

\section{References}

1. Chen W, Zheng R, Baade PD, Zhang S, Zeng H, Bray F, Jemal A, Yu XQ, He J. Cancer statistics in China, 2015. CA Cancer J Clin. 2016;66(2):115-32.

2. Grazi GL, Ercolani G, Pierangeli F, Del Gaudio M, Cescon M, Cavallari A, Mazziotti A. Improved results of liver resection for hepatocellular carcinoma on cirrhosis give the procedure added value. Ann Surg. 2001;234(1):71-8

3. Wang YY, Zhong JH, Su ZY, Huang JF, Lu SD, Xiang BD, Ma L, Qi LN, Ou BN, Li LQ. Albumin-bilirubin versus Child-Pugh score as a predictor of outcome after liver resection for hepatocellular carcinoma. Br J Surg. 2016;103(6):725-34.

4. Dong J, Xu XH, Ke MY, Xiang JX, Liu WY, Liu XM, Wang B, Zhang XF, $L \vee Y$. The FIB-4 score predicts postoperative short-term outcomes of hepatocellular carcinoma fulfilling the milan criteria. Eur J Surg Oncol. 2016;42(5):722-7.

5. Farges O, Malassagne B, Flejou JF, Balzan S, Sauvanet A, Belghiti J. Risk of major liver resection in patients with underlying chronic liver disease: a reappraisal. Ann Surg. 1999;229(2):210-5.

6. Nagasue N, Kohno H, Tachibana M, Yamanoi A, Ohmori H, El-Assal ON. Prognostic factors after hepatic resection for hepatocellular carcinoma associated with Child-Turcotte class B and C cirrhosis. Ann Surg. 1999;229(1):84-90.

7. Kladney RD, Cui X, Bulla GA, Brunt EM, Fimmel CJ. Expression of GP73, a resident Golgi membrane protein, in viral and nonviral liver disease. Hepatology. 2002;35(6):1431-40.

8. Marrero JA, Romano PR, Nikolaeva O, Steel L, Mehta A, Fimmel CJ, Comunale MA, D'Amelio A, Lok AS, BlockTM. GP73, a resident Golgi glycoprotein, is a novel serum marker for hepatocellular carcinoma.J Hepatol. 2005;43(6):1007-12.

9. Block TM, Comunale MA, Lowman M, Steel LF, Romano PR, Fimmel C, Tennant BC, London WT, Evans AA, Blumberg BS, et al. Use of targeted glycoproteomics to identify serum glycoproteins that correlate with liver cancer in woodchucks and humans. Proc Natl Acad Sci USA. 2005;102(3):779-84

10. Wei H, Li B, Zhang R, Hao X, Huang Y, Qiao Y, Hou J, Li X, Li X. Serum GP73, a marker for evaluating progression in patients with chronic HBV infections. PLOS ONE. 2013;8(2):e53862.

11. Qiao Y, Chen J, Li X, Wei H, Xiao F, Chang L, Zhang R, Hao X, Wei H. Serum gp73 is also a biomarker for diagnosing cirrhosis in population with chronic HBV infection. Clin Biochem. 2014:47(16-17):216-22.

12. Johnson PJ, Berhane S, Kagebayashi C, Satomura S, Teng M, Reeves HL, O'Beirne J, Fox R, Skowronska A, Palmer D, et al. Assessment of liver function in patients with hepatocellular carcinoma: a new evidence-based approach-the ALBI grade. J Clin Oncol. 2015;33(6):550-8.

13. Suh B, Park S, Shin DW, Yun JM, Yang HK, Yu SJ, Shin Cl, Kim JS, Ahn E, Lee $\mathrm{H}$, et al. High liver fibrosis index FIB-4 is highly predictive of hepatocellular carcinoma in chronic hepatitis B carriers. Hepatology. 2015;61(4):1261-8.

14. Naveau S, Gaude G, Asnacios A, Agostini H, Abella A, Barri-Ova N, Dauvois B, Prevot S, Ngo Y, Munteanu M, et al. Diagnostic and prognostic values of noninvasive biomarkers of fibrosis in patients with alcoholic liver disease. Hepatology. 2009:49(1):97-105. 
15. Dindo D, Demartines N, Clavien PA. Classification of surgical complications: a new proposal with evaluation in a cohort of 6336 patients and results of a survey. Ann Surg. 2004;240(2):205-13.

16. Mas VR, Maluf DG, Archer KJ, Yanek K, Kong X, Kulik L, Freise CE, Olthoff KM, Ghobrial RM, Mclver P, et al. Genes involved in viral carcinogenesis and tumor initiation in hepatitis $C$ virus-induced hepatocellular carcinoma. Mol Med. 2009;15(3-4):85-94.

17. Taura K, Ikai I, Hatano E, Yasuchika K, Nakajima A, Tada M, Seo S, Machimoto T, Uemoto S. Influence of coexisting cirrhosis on outcomes after partial hepatic resection for hepatocellular carcinoma fulfilling the Milan criteria: an analysis of 293 patients. Surgery. 2007;142(5):685-94.

18. Huang H, Tohme S, Al-Khafaji AB, Tai S, Loughran P, Chen L, Wang S, Kim J, Billiar T, Wang Y, et al. Damage-associated molecular pattern-activated neutrophil extracellular trap exacerbates sterile inflammatory liver injury. Hepatology. 2015;62(2):600-14.

19. Kaibori M, Kwon AH, Nakagawa M, Wei T, Uetsuji S, Kamiyama Y, Okumura T, Kitamura N. Stimulation of liver regeneration and function after partial hepatectomy in cirrhotic rats by continuous infusion of recombinant human hepatocyte growth factor. J Hepatol. 1997;27(2):381-90.

20. Corpechot C, Barbu V, Wendum D, Chignard N, Housset C, Poupon R, Rosmorduc O. Hepatocyte growth factor and c-Met inhibition by hepatic cell hypoxia: a potential mechanism for liver regeneration failure in experimental cirrhosis. Am J Pathol. 2002;160(2):613-20.

21. Kazankov K, Barrera F, Moller HJ, Bibby BM, Vilstrup H, George J, Gronbaek H. Soluble CD163, a macrophage activation marker, is independently associated with fibrosis in patients with chronic viral hepatitis B and C. Hepatology. 2014;60(2):521-30.

22. Xiao G, Yang J, Yan L. Comparison of diagnostic accuracy of aspartate aminotransferase to platelet ratio index and fibrosis-4 index for detecting liver fibrosis in adult patients with chronic hepatitis B virus infection: a systemic review and meta-analysis. Hepatology. 2015:61(1):292-302.

23. Ganne-Carrie N, Ziol M, de Ledinghen V, Douvin C, Marcellin P, Castera $L$, Dhumeaux D, Trinchet JC, Beaugrand M. Accuracy of liver stiffness measurement for the diagnosis of cirrhosis in patients with chronic liver diseases. Hepatology. 2006;44(6):1511-7.

24. Cao Z, Li Z, Wang Y, Liu Y, Mo R, Ren P, Chen L, Lu J, Li H, Zhuang Y, et al. Assessment of serum Golgi protein 73 as a biomarker for the diagnosis of significant fibrosis in patients with chronic HBV infection. J Viral Hepatitis. 2017;24(Suppl 1):57-65.

25. Hiraoka A, Kumada T, Michitaka K, Toyoda H, Tada T, Ueki H, Kaneto M, Aibiki T, Okudaira T, Kawakami T, et al. Usefulness of albumin-bilirubin grade for evaluation of prognosis of 2584 Japanese patients with hepatocellular carcinoma. J Gastroenterol Hepatol. 2016;31(5):1031-6.

26. Pinato DJ, Sharma R, Allara E, Yen C, Arizumi T, Kubota K, Bettinger D, Jang JW, Smirne C, Kim YW, et al. The ALBI grade provides objective hepatic reserve estimation across each BCLC stage of hepatocellular carcinoma. J Hepatol. 2017;66(2):338-46.

27. Toyoda H, Lai PB, O'Beirne J, Chong CC, Berhane S, Reeves H, Manas D, Fox RP, Yeo W, Mo F, et al. Long-term impact of liver function on curative therapy for hepatocellular carcinoma: application of the ALBI grade. $\mathrm{Br}$ J Cancer. 2016;114(7):744-50.

28. Mao Y, Yang H, Xu H, Lu X, Sang X, Du S, Zhao H, Chen W, Xu Y, Chi T, et al. Golgi protein 73 (GOLPH2) is a valuable serum marker for hepatocellular carcinoma. Gut. 2010;59(12):1687-93.

29. Wang Y, Yang H, Xu H, Lu X, Sang X, Zhong S, Huang J, Mao Y. Golgi protein 73 , not glypican-3, may be a tumor marker complementary to alpha-Fetoprotein for hepatocellular carcinoma diagnosis. J Gastroenterol Hepatol. 2014;29(3):597-602.

30. Wang $M$, Long RE, Comunale MA, Junaidi O, Marrero J, Di Bisceglie AM, Block TM, Mehta AS. Novel fucosylated biomarkers for the early detection of hepatocellular carcinoma. Cancer Epidemiol Biomark Prev. 2009;18(6):1914-21.

31. Liu T, Yao M, Liu S, Wang L, Wang L, Hou J, Ma X, Jia J, Zhao J, Zhuang $\mathrm{H}$, et al. Serum Golgi protein 73 is not a suitable diagnostic marker for hepatocellular carcinoma. Oncotarget. 2017;8(10):16498-506.
Ready to submit your research? Choose BMC and benefit from:

- fast, convenient online submission

- thorough peer review by experienced researchers in your field

- rapid publication on acceptance

- support for research data, including large and complex data types

- gold Open Access which fosters wider collaboration and increased citations

- maximum visibility for your research: over $100 \mathrm{M}$ website views per year

At $\mathrm{BMC}$, research is always in progress.

Learn more biomedcentral.com/submissions 